\title{
Breeding for Cold Hardiness: Searching for Genes to Improve Fruit Quality in Cold-hardy Peach Germplasm
}

\author{
Ann Callahan, Ralph Scorza, Peter Morgens, Seth Mante, John Cordts, and Reuben Cohen \\ U.S. Department of Agriculture, Agricultural Research Service, Appalachian Fruit Research Station, \\ Kearneysville, WV 25430
}

\section{STRATEGY FOR IMPROVING PEACH GERMPLASM}

The generation of cold-hardy cultivars with high-quality fruit has long been a goal of peach breeding programs. While progress has been made, these traits have been difficult to combine by traditional breeding methods. Both cold hardiness and fruit quality are general terms that encompass various specific traits, many of which may be quantitatively inherited. Thus, many generations of hybridization and selection are required to combine several favorable alleles for both of these characteristics. Moreover, certain aspects of cold hardiness may be physiologically or morphologically incompatible with certain aspects of fruit quality, and/or major genes responsible for certain aspects of cold hardiness may be closely linked with particular genes influencing fruit quality.

Advances in plant regeneration, molecular biology, and gene transfer (Broglie et al., 1984; DeBlock et al., 1984; Fillatti et al., 1987; McGranahan et al., 1988; Murai et al., 1983; Parsons et al..
1986) suggest a novel strategy for the development of cold-hardy, high fruit quality cultivars: the manipulation of specific traits through genetic engineering. Such a strategy would allow breeders to manipulate selectively genes that affect cold hardiness or fruit quality through gene transfer without the necessity of the sexual cycle and the recombination of genes that results from this process.

We have chosen not to attempt manipulation of cold-hardiness traits for the following reasons: a) Little is understood about the enzymology of cold hardiness. Without this knowledge, the correlation of gene expression with cold hardiness is difficult, at best. b) Cold hardiness encompasses various tolerance or avoidance mechanisms, including early dormancy in the fall, low-temperature resistance in midwinter, delayed response to warming temperatures, and late blooming. The physiological and genetic relationships of these factors are not known. In any particular climatic situation, one of these factors may have an overriding effect on hardiness not evident under a different set of cold stress conditions. c) Cold har- 
diness of various plant tissues may differ on the same tree such that selection for hardiness of one tissue does not guarantee that other tissues of that genotype will be cold-hardy. Cold hardiness of flower buds and shoot xylem appear to be inherited independently (Layne, 1982). d) Evaluation of cold hardiness is difficult and time-consuming. Screening must be repeated for at least several years to partition out the strong environmental component of variability. While the genetic manipulation of cold hardiness through genetic engineering does not appear to be the most efficient strategy for peaches at present, advances in our knowledge of the molecular biology, physiology, and morphology of cold hardiness may suggest this approach in the future.

We have chosen to attempt to manipulate fruit quality traits for the following reasons: a) Ultimately, fruit production depends on consumer acceptance of the final product; hence, fruit is the most important aspect. This realization has encouraged various studies concerning the biochemistry and enzymology of fruit development and quality (Romani and Jennings, 1972; Sistrunk, 1985). The processing industry has been particularly concerned with peach fruit enzymology. Such knowledge lays the groundwork for studies of gene expression. b) While fruit development and quality encompass diverse processes, these processes, for the most part, are limited to fruit tissue. Studies of gene expression can, therefore, be carried out only on the fruit. c) Although fruit quality is influenced by environment, its influence is minor and relative differences in fruit quality between genotypes is consistent (Sistrunk, 1985). d) Fruit quality is evaluated on fruit tissue and does not require the sampling and evaluation of multiple tissue types or organs.

As summarized above, we consider the genetic manipulation of specific aspects of fruit quality to be, at present, more feasible than the manipulation of cold hardiness. We are studying gene expression in peach fruit with the long-term goal of manipulating fruit quality by the insertion of few genes into cultivars that are coldhardy but bear-commercially unacceptable fruit. Although physiological and/or morphological incompatibilities between cold hardiness and fruit quality could not be overcome in this way, gene linkages between traits of interest could be. We may be able to take advanced cold-hardy breeding selections with a reasonable level of fruit quality and achieve the fruit improvement necessary for elevating that selection to a cultivar through specific gene transfer. To this end, we are studying the molecular biology of peach fruit development/fruit quality and are developing the technology to transform and regenerate peach plants.

\section{PEACH FRUIT QUALITY}

Peach fruit quality is a general term encompassing size, color, texture, softening, flavor, aroma, and other factors to which consumers are sensitive (Sistrunk, 1985; Sistrunk and Moore, 1983). A promising aspect of studying fruit quality is the strong genetic control of some quality characteristics. Single gene loci (Table 1) appear to be responsible for freestone, melting flesh, white flesh, nectarine, saucer-shape fruit, double fruit, sweet (low malic acid content) fruit, and "stony hard" flesh texture (Bailey and French, 1949; Monet, 1983; Yoshida, 1976). There is also evidence from crosses between almond and peach that major differences in exocarp color (green vs. red), mesocarp (dry, hard vs. tender, juicy), endocarp (smooth vs. furrowed), and seed (sweet vs. bitter) may each be controlled by one or a few major genes (De Terraciano and Cialzeta, 1979). The fact that these characteristics appear to be controlled by few major genes suggests that their manipulation could measurably change fruit quality.

Other aspects of fruit quality, including fruit size (Hansche et al., 1972), acid content (Yoshida, 1970), and total soluble solids content (Hansche and Boynton, 1986), are quantitative traits with moderately high heritabilities. The number of genes involved in the expression of these traits is not known. Whether such traits can be affected practically by insertion of a few genes is unclear. If the phenotypes are affected by major genes with modifiers, manipulating the major genes may produce significant effects.

There have been numerous biochemical studies of peach fruit involving color, flavor, texture, and softening (Do et al., 1969;
Table 1. Peach fruit traits apparently regulated by one gene.

\begin{tabular}{lcl}
\hline \hline Trait & Characteristic & Literature cited \\
\hline Freestone & Dominant & Bailey and French, 1933 \\
Melting flesh & Dominant & Bailey and French, 1933 \\
White flesh & Dominant & Connors, 1920 \\
Nectarine & Recessive & Blake, 1938 \\
Saucer shape & Dominant & Lesley, 1940 \\
Double fruit & Dominant & Lesley, 1940 \\
Sweet fruit & Dominant & Monet, 1979 \\
Soft flesh & Dominant & Yoshida, 1976 \\
\hline
\end{tabular}

Sistrunk, 1985). Levels of acids, sugars, soluble solids content, and polyphenols differ among cultivars (Sistrunk, 1985). When these biochemical aspects of quality were compared among commercially acceptable and unacceptable genotypes, only polyphenol levels and $\mathrm{pH}$ differences appeared to correlate with these two fruit classes (Robertson et al., 1988; Yoshida, 1970). Polyphenols are an important factor related to fruit astringency and flavor (Sistrunk, 1985). Differences in aromatic components have also been examined between high- and low-quality fruit cultivars (Horvat et al., 1990). Major differences were found in the C6-alcohol/C6-aldehyde, linalool/nonanol, and gamma-C10 lactone compounds.

The levels of several enzymes have been measured and correlated with traits that would be desirable to manipulate. Among these are polyphenoloxidase, which, along with polyphenols, is associated with undesirable flesh browning (Hansche and Boynton, 1986), and polygalacturonases (endo and exo) that break down long chain pectins and presumably participate in softening (Pressey and Avants, 1976; Pressey et al., 1971; Yoshida, 1976). Endopolygalacturonase levels are also associated with differences between melting and nonmelting flesh fruit (Pressey and Avants, 1978). Thus, endopolygalacturonase is a candidate for genetic manipulation because softening is an important trait in the peach industry.

The viability of a gene isolation and transfer approach to the manipulation of fruit quality traits depends on the capability to: 1) identify and isolate genes of horticultural value, 2) transform and regenerate peach trees, and 3) regulate expression of transferred genes. We report here a summary of strategies that we are using and our results to date.

\section{EXPERIMENTAL STRATEGIES AND RESULTS}

\section{Strategies for identifying and isolating genes}

Two approaches are being used to identify genes of potential interest: a) differential hybridization of cDNA libraries and b) isolation of genes of known enzymes by hybridization to homologous probes from other organisms. The first approach involves identifying and isolating genes that are expressed at different levels or times between two fruit having genetically different traits of interest (for example, melting vs. nonmelting flesh). This identification is being done by constructing cDNA libraries (collections of DNA sequences complementary to the RNA sequences present in the fruit at the time of sampling) from fruit mRNAs of the desired developmental stage, hybridizing the library with cDNAs from the two fruit types of interest (i.e., melting and nonmelting flesh), and isolating clones that hybridize preferentially to one fruit type.

The second approach involves isolating genes for known enzymes that may affect fruit quality. These are genes such as for polyphenoloxidase and endopolygalacturonase, pathway genes for phenolic and aromatic compounds, and growth hormone pathway genes. Isolation is accomplished by a) using genes already cloned in other systems to identify and isolate the comparable gene in peach or b) using known protein sequences to generate oligonucleotide sequences to use as probes for the isolation of the comparable gene in peach. Antibodies could also be used to identify clones producing antigenically related proteins of peach.

Isolation of genes whose expression differs between a high-quality and a low-quality peach fruit. In a preliminary study, changes in mRNA species during fruit development were examined to determine if regulation of development was detectable at the mRNA 
level. Total RNAs from 10 periods of fruit development were translated into polypeptides in an in vitro translation system and indicated that changes occurred at the RNA level during fruit development (Callahan et al., 1989). The detectable changes in RNA species appeared in early fruit development, with no detectable changes seen during final swell and ripening. RNAs from two commercialquality cultivars ('Suncrest' and 'Loring') and two low-quality, coldhardy cultivars ('Boone County' and 'Bailey') were then compared by examining in vitro translation products. There are major phenotypic differences among these cultivars that include yellow vs. white flesh, slow vs. fast softening, low vs. high phenolic levels, and large vs. small fruit, respectively. The translations were done to determine the level of differences that could be detected and when, during the course of development, these differences occurred. The resultant polypeptide patterns were remarkably similar in all the cultivars at most times of development. A noteworthy exception was at 30 days after bloom, when three polypeptides were present at higher levels in the higher quality 'Suncrest' and 'Loring' than in 'Boone' and 'Bailey'. The few differences in mRNA translation products suggests that either in vitro translations of mRNAs are not sensitive enough to detect the level of genetic differences responsible for different fruit phenotypes or fruit development is similar in these high- and low-quality fruit.

To study RNA differences at a more sensitive level, a cDNA library was constructed from mRNA extracted from 'Suncrest' fruit 30 days after bloom. We isolated specific cDNA clones that represented mRNAs expressed at a higher level in 'Suncrest' fruit 30 days after bloom than in 'Bailey' fruit of the same age. Twelve clones satisfied our selection criteria after a second screen. To avoid duplication, characterization continued with only the five clones that had unique insert sizes. The developmental expression of the genes complimentary to the clones was examined by hybridizing clones to RNAs isolated from fruit at different stages of development. The patterns of hybridization are summarized in Table 2 . The results of these experiments support the translation data in that few differences were detectable. Based on our experience, differences should have been more readily detected through hybridizations of cDNA clones than through in vitro translations.

To determine if the selected cDNA clones correlated with any obvious phenotypes, other high and low fruit quality cultivars were tested to determine the expression pattern of the genes. Two genes had higher levels of expression in the three high fruit quality cultivars examined than in the two low fruit quality cultivars examined.
Isolation of genes that are induced during peach softening. Differential hybridization is also being used to identify genes that are induced during softening. A cDNA library was constructed representing mRNAs from 'Loring' fruit that were collected at a stage when the pressure necessary to force a 7-mm-diameter plunger into the mesocarp was <20 N (2 Kg; "soft ripe"). Clones were isolated that represented mRNAs expressed at a greater level at one time in softening than at another time in softening in 'Loring'. Expression of the homologous genes is summarized in Table 2. These clones are being used as probes to compare softening in cultivars with different ripening phenotypes (such as nonmelting vs. melting flesh) and cultivars that soften at different rates.

Isolation of genes for known enzymes. The second approach is to identify enzymes and isolate the genes for those enzymes that may be involved in quality traits. Two peach fruit cDNA clones have been isolated by their homology to regions of a tomato endopolygalacturonase cDNA clone. One peach cDNA clone with homology to a cucumber peroxidase cDNA clone has been isolated.

\section{Regeneration}

Peach plants have been regenerated from somatic embryos derived from immature embryos and from endosperm tissue (Hammerschlag et al., 1985; Meng and Zhou, 1981). These regeneration systems require the use of regenerative explants during a short period during the growing season. We have obtained habituated embryogenic callus derived from immature embryos. This callus has continued to proliferate somatic embryos for more than three years in the absence of exogenously applied growth regulators. At this point, $\approx 10 \%$ of the calli regenerate plants.

Relatively many peach plants can be regenerated from immature cotyledons (Mante et al., 1989). Optimum regeneration from the cultivars tested has been obtained from cotyledons excised $\approx 70$ days postbloom and cultured on a Murashige and Skoog-based medium (Murashige and Skoog, 1962) with $2.5 \mu \mathrm{M}$ indole butyric acid and 5 to $12.5 \mu \mathrm{M} \mathrm{N}$-phenyl-N'-1,2,3-thiadiazol-5-ylurea (thidiazuron). The cotyledons can be stored at $4 \mathrm{C}$ for up to 90 days without loss in regeneration potential. Shoot regeneration from mature treederived somatic tissue has thus far been unsuccessful, although root regeneration from such tissue is common under the proper conditions. Failure of shoot regeneration from mature tissue is a major problem in the use of tissue culture technologies for direct cultivar improvement of peach. The use of seed-derived material will allow

Table 2. Partial characterization of cDNA clones.

\begin{tabular}{|c|c|c|}
\hline $\begin{array}{l}\text { Clone } \\
\text { RNA size } \\
\end{array}$ & Source & Characteristic expression \\
\hline Sun-A2, n.d. & $\begin{array}{l}\text { Suncrest fruit } \\
30 \text { days after bloom }\end{array}$ & $\begin{array}{l}\text { 2-fold higher in Suncrest than Bailey throughout de- } \\
\text { velopment }\end{array}$ \\
\hline Sun-A3, 950 & $\begin{array}{l}\text { Suncrest fruit } \\
30 \text { days after bloom }\end{array}$ & $\begin{array}{l}4 \text { to } 5 \text {-fold higher in Suncrest than Bailey, increas- } \\
\text { ing throughout development }\end{array}$ \\
\hline Sun-A6, n.d. & $\begin{array}{l}\text { Suncrest fruit } \\
30 \text { days after bloom }\end{array}$ & Detected only at 30 days after bloom in Suncrest \\
\hline Sun-A8, n.d. & $\begin{array}{l}\text { Suncrest fruit } \\
30 \text { days after bloom }\end{array}$ & $\begin{array}{l}\text { Higher in Bailey leaf than in Suncrest leaf, equally } \\
\text { expressed in fruit until } 30 \text { days, then undetectable }\end{array}$ \\
\hline Sun-A15, 950 & $\begin{array}{l}\text { Suncrest fruit } \\
30 \text { days after bloom }\end{array}$ & $\begin{array}{l}4 \text { to } 5 \text { fold higher in Suncrest than Bailey, increasing } \\
\text { throughout development }\end{array}$ \\
\hline $61-\mathrm{P} 2,1600$ & $\begin{array}{l}612615 \text { fruit } \\
122 \text { days after bloom }\end{array}$ & Detectable only in softest fruit \\
\hline $61-P 3,1000$ & $\begin{array}{l}612615 \text { fruit } \\
122 \text { days after bloom }\end{array}$ & Softening specific \\
\hline L4-R1, 1000 & $\begin{array}{l}\text { Loring fruit } \\
22 \mathrm{~kg} \text { pressure }\end{array}$ & Softening specific \\
\hline LA-R2, 800 & $\begin{array}{l}\text { I oring fruit } \\
2 \mathrm{~kg} \text { pressure }\end{array}$ & Softening specific \\
\hline L4-R5, 1200 & $\begin{array}{l}\text { Loring fruit } \\
2 \mathrm{~kg} \text { pressure }\end{array}$ & Expression varies among cultivars \\
\hline Sun-P4, 1200 & $\begin{array}{l}\text { Suncrest fruit } \\
30 \text { davs after hlonm }\end{array}$ & Varying patterns of expression \\
\hline
\end{tabular}

${ }^{2}$ Size in number of bases; n.d. = size not determined. 
for the improvement of seed-propagated rootstocks and scion germplasm but will not be directly applicable to the improvement of existing scion cultivars. The relative uniformity of the cold-hardy rootstocks being used in our program, such as 'Bailey' (Layne, 1987), and the capability to regenerate multiple plants per seed should allow for the use of seed-derived material to test the potential of fruit quality manipulation through specific gene insertions.

\section{Transformation}

Peach internodes, leaf pieces, and embryogenic callus have been exposed to the engineered Agrobacterium tumefaciens binary vector 6044 (supplied by G. An, Washington State Univ., Pullman). This vector carries the NOS-NPT II-NOS chimeric gene on pGA472 and the vir and tumor-inducing genes $(t m s / t m r)$ on the helper plasmid pTiBo542. Growth of callus from these three explant sources on selective medium containing kanamycin or geneticin has indicated transformation. Transformation has been verified by Southern analyses (i.e., DNA has been extracted from the transformed tissue and the presence of the inserted DNA verified by its homology to the vector DNA) (Southern, 1975). Regeneration of shoots was not expected from the leaf or internode explants. The use of the armed binary vector 6044 on embryogenic calli would be expected to yield both tumorigenic and nontumorigenic transformants (An et al., 1985). Thus far, only tumorigenic putative transformants have been obtained and shoots have not been produced.

\section{Strategies toward identification of gene function}

The function of isolated genes may be tested in two ways. The production of mRNAs specific to that gene may be blocked by constructing an antisense RNA using the cDNA clone together with a strong, constitutive promoter. This construct can then be engineered into a Ti plasmid for transformation, via A. tumefuciens, of appropriate peach cultivars. This approach theoretically would produce phenotypes ranging from no effect to the equivalent of a null mutation (Smith et al., 1988; Van der Krol et al., 1988). A second method involves isolation of the gene of interest with its own regulatory/promoter region from a genomic library. The gene can be engineered into a $\mathrm{Ti}$ plasmid vector and used to transform various peach cultivars in which the expression of that gene differs (Giovannoni et al., 1989). Regenerated transgenic plants can then be used to test the effect of having the gene expressed at different amounts and times. With either manner of testing function, after measuring RNA expression, the fruit must be examined in comparison with control fruit (nontransformed and transformed with the vector only) for phenotypic and biochemical alterations. Thus, a regeneration/transformation system for peach is essential.

\section{CONCLUSIONS}

The potential of research on gene expression lies in the improvement of fruit quality, but more immediate results will provide a better understanding of fruit development and fruit quality. We should begin to learn how differences at the gene level in different cultivars correlate with quality characteristics and whether differences are so numerous as to make it impossible to manipulate or test them. With the continued cooperation of fruit biochemists, we expect to obtain a better definition of fruit quality and a better understanding of fruit biochemistry. By comparing high- and lowquality fruit biochemically, aspects relating to commercial quality and consumer preference may be better understood. The potential will exist to generate a range of "antisense mutants" through antisense constructions. The phenotypes of these mutants could help to define the biochemistry, genetics, and quality aspects of fruit. These antisense genes could be used as markers in breeding. Insights may be gained into the relationship between tree cold hardiness and fruit quality. We may be able to examine whether aspects of cold hardiness and fruit quality are mutually exclusive due to physiology or morphology or if they are closely linked genetically.

As new sources of peach germplasm are exploited for disease resistance, insect resistance, and cold hardiness, the development of commercially acceptable fruit will be a major factor delaying cultivar release. An understanding of the genetics, molecular biology, and biochemistry will be critical for efficient progress, whether this progress proceeds through conventional or alternative breeding techniques.

\section{Literature Cited}

An, G., B.D. Watson, S. Stachel, M.P. Gordon, and E.W. Nester. 1985. New cloning vehicles for transformation of higher plants. EMBO J. 4:277284.

Bailey, J.S. and A.P. French. 1933. The inheritance of certain characters in the peach. Proc. Amer. Soc. Hort. Sci. 29:127-130.

Bailey, JS. and A.P. French. 1949. The inheritance of certain fruit and foliage characters in the peach. Massachusetts Agr. Expt. Sta. Bul. 452.

Blake, M.A. 1938. Progress in peach breeding. Proc. Amer. Soc. Hort. Sci. 35:49-53.

Broglie, R., G. Coruzzi, R.T. Fraley, S.G. Rogers, R.B. Horsch, J.G. Niedermeyer, C.L. Fink, J.S. Flick, and N.H. Chua. 1984. Light-regulated expression of a pea ribulose-1-5-bisphosphate carboxylase small sub-unit gene in transformed plant cells. Science 224:838-843.

Callahan, A., P. Morgens, and E. Walton. 1989. Isolation and in vitro translation of RNAs from developing peach fruit. HortScience 24:356358.

Connors, C.H. 1920. Some notes on the inheritance of unit characters in the peach. Proc. Amer. Soc. Hort. Sci. 16:24-36.

DeBlock, M., L. Herrera-Estrella, M. Van Montagu, J. Schell, and P. Zambryski. 1984. Expression of foreign genes in regenerated plants and their progeny. EMBO J. 3:1681-1689.

De Tepaciano, L.B.C. and C. Cialzeta. 1979. Interspecific crosses as a method to breed Prunus persica and Prunus amygdalus. Bol. Gener. Inst. Fitotec. Castetar 10:25-29.

Do, J.Y., D.K. Salunkhe, and L.E. Olson. 1969. Isolation, identification and comparison of the volatiles of peach fruit as related to harvest maturity and artificial ripening. J. Food Sci. 34:618-621.

Fillatti, J.J., J. Sellmer, B. McCown, B. Hassig, and L. Comai. 1987. Agrobacterium mediated transformation and regeneration of Populus. Mol. Gen. Genet. 206:192-199.

Giovannoni, J.J., D. Della Penna, A.B. Bennett, and R.L. Fischer. 1989. Expression of a chimeric polygalacturonase gene in transgenic rin (ripening inhibitor) tomato fruit results in polyuronide degradation but not fruit softening. The Plant Cell 1:53-63.

Hammerschlag, F.A., G. Bauchan, and R. Scorza. 1985. Regeneration of peach plants from callus derived from immature embryos. Theor. Appl. Genet. 70:248-251.

Hansche, P.E. and B. Boyuton. 1986. Heritability of enzymatic browning in peaches. HortScience 21:1195-1197.

Hansche, P.E., C.O. Hesse, and V. Beres. 1972. Estimates of genetic and environmental effects on several traits in peach. J. Amer. Soc. Hort. Sci. 97:76-79.

Horvat, R.J., G.W. Chapman, J.A. Robertson, F.I. Meredith, R. Scorza, A.M. Callahan, and P.H. Morgens. 1990. Comparison of the volatile compounds from several commercial peach cultivars. J. Agr. Food Chem. 38:234-237.

Layne, R.E.C. 1982. Cold hardiness of peaches and nectarines following a test winter. Fruit Var. J. 36:90-98.

Layne, R.E.C. 1987. Peach rootstocks, p. 185-216. In. R.C. Rom and R.F. Carlson (eds.). Rootstocks for fruit crops. Wiley, New York.

Lesley, J.W. 1940. A genetic study of saucer fruit shape and other characters in the peach. Proc. Amer. Soc. Hort. Sci. 37:218-222.

Mante, S., R. Scorza, and J.M. Cordts. 1989. Plant regeneration from cotyledons of Prunus persica, Prunus domestica, and Prunus cerasus. Plant Cell, Tissue \& Organ Culture. 19:1-11.

McGranahan, G.H., C.A. Leslie, S.L. Uratsu, L.A. Martin, and A.M. Dandekar. 1988. Agrobacterium-mediated transformation of walnut somatic embryos and regeneration of transgenic plants. Bio/Technology 6:800-804.

Meng, X. and W. Zhou. 1981. Induction of embryoid and production of plantlets in vitro from endospermof peach (In Chinese). Acta Agr., Univ. of Peking. 7:95-98.

Monet, R. 1979. Transmission genetique du caractere "fruit doux" chez le pêcher. Incidence sur la selection pour la qualite. Symposium EUCARPIA Amelioration des Arbre Fruitiers, ANGERS, 3-5 Sept.

Monet, R. 1983. Le pêcher genetique et physiologie. Masson, Paris. p. 2443.

Murai, N., D.W. Sutton, M.G. Murray, J.L. Slightom, D.J. Merlo, N.A. Reichert, C. Sengupta-Gopalan, C.A. Stock, R.F. Barker, J.D. Kemp, and T.C. Hall. 1983. Phaseolin gene from bean is expressed after transfer to sunflower via tumor-inducing plasmid vectors. Science 222:476-482.

Murashige, T. and F. Skoog. 1962. A revised medium for rapid growth and 
bioassays with tobacco tissue cultures. Physiol. Plant. 15:473-497.

Parsons, T.J., V.P. Sinkar, E.W. Nester, and M.P. Gordon. 1986. Transformation of poplar by Agrobacterium tumefaciens. Bio/Technology 4:533536.

Pressey, R. and J.K. Avants. 1976. Separation and characterization of endopolygalacturonase and exopolygalacturonase from peaches. Plant Physiol. 52:252-256.

Pressey, R. and J.K. Avants. 1978. Difference in polygalacturonase composition of clingstone and freestone peaches. J. Food Sci. 43:1415-1423.

Pressey, R., D.M. Hinton, and J.K. Avants. 1971. Development of polygalacturonase activity and solubilization of pectin in peaches during ripening. J. Food Sci. 36:1070-1073.

Robertson, J.A., R.I. Meredith, and R. Scorza. 1988. Characteristics of fruit from high and low quality peach cultivars. HortScience 23:10321034

Romani, R.J. and W.G. Jennings. 1972. Stone fruits, p. 411-435. In: A.C. Hulme (ed.). The biochemistry of fruits and their products. vol. 2. Academic, New York.

Sistrunk, W.A. 1985. Peach quality assessment: Fresh and processed, p.
146. In: H.E. Pattee (ed.). Evaluation of quality of fruits and vegetables. AVI Publishing, Westport, Conn.

Sistrunk, W.A. and J.N. Moore. 1983. Quality, p. 274-293. In: J.N. Moore and J. Janick (eds.). Methods in fruit breeding. Purdue University Press, West Lafayette, Ind.

Smith, C.J.S., C.F. Watson, J. Ray, C.R. Bird, P.C. Morris, W. Schuch, and D. Grierson. 1988. Antisense RNA inhibition of polygalacturonase gene expression in transgenic tomatoes. Nature 334:724-726.

Southern, E. 1975. Detection of specific sequences among DNA fragments separated by gel electrophoresis. J. Mol. Biol. 98:503.

Van der Krol, A.R., P.E. Lenting, J. Veenstra, I.M. van der Meer, R.E. Koes, A.G.M. Gerats, J.N.M. Mol, and A.R. Stuitje. 1988. An antisense chalcone synthase gene in transgenic plants inhibits flower pigmentation. Nature 333:866-869.

Yoshida, M. 1970. Genetical studies on the fruit quality of peach varieties I. Acidity. Bul. Fruit Tree Res. Sta. (Hiratsuka) 9:1-15.

Yoshida, M. 1976. Genetical studies on the fruit quality of peach varieties III. Texture and keeping quality. Bul. Fruit Tree Res. Sta. (Hiratsuka) $3: 1-16$. 